\title{
HUBUNGAN POLA ASUH ORANG TUA DENGAN PERKEMBANGAN ANAK PRA SEKOLAH DI TK MENTARI DESA SAMBI RAMPAK LOR KECAMATAN KOTA ANYAR KABUPATEN PROBOLINGGO
}

\author{
Widia Shofa Ilmiah $^{1)}$, Fifin Maulidatul Azizah ${ }^{2}$, Nina Sukma Amelia ${ }^{3)}$ \\ Program Studi D IV Bidan Pendidik, Sekolah Tinggi Ilmu Kesehatan Hafshawaty Zainul Hasan \\ email: widiailmiah@yahoo.com
}

\begin{abstract}
ABSTRAK
Periode lima tahun pertama kehidupan merupakan masa yang sangat peka terhadap lingkungan dan berlangsung sangat pendek serta tidak dapat diulang lagi, maka masa tersebut disebut "masa keemasan" (golden period). Dari data penelitian sebelumnya menunjukkan bahwa 14\% balita Indonesia mengalami gangguan perkembangan, baik perkembangan motorik halus dan kasar, gangguan pendengaran, kecerdasan kurang dan keterlambatan bicara. Hasil studi pendahuluan di TK Mentari diketahui dari 5 anak, terdapat dua anak mengalami gangguan perkembangan sosial kemandirian. Hal ini disebabkan faktor ekstrinsik meliputi pola asuh orang tua, faktor ekonomi, lingkungan, gizi anak. Tujuan Penelitian ini adalah untuk mengetahui hubungan pola asuh orang tua dengan perkembangan anak pra sekolah di TK Mentari Desa Sam bi Rampak Lor Kecamatan Kota Anyar Kabupaten Probolinggo. Penelitian ini menggunakan desain kuantitatif jenis analitik korelasional dengan pendekatan cross sectional. Populasi yaitu seluruh ibu dan anak pra sekolah di TK Mentari Tahun 2015. Sampel yaitu sebagian ibu dan anak pra sekolah sejumlah 50 responden. Teknik sampling yaitu purposive sampling dengan uji statistik Spearman Rank. Hasil penelitian menunjukkan $p$ value 0,04< $\alpha(0,05)$, sehingga HO di tolak. Kesimpulan yaitu ada hubungan pola asuh orang tua dengan perkembangan anak pra sekolah di TK Mentari Desa Sambi Rampak Lor Kecamatan Kota Anyar Kabupaten Probolinggo.
\end{abstract}

Kata kunci : pola asuh, perkembangan, anak pra sekolah

\begin{abstract}
The life period of the first five years is a moment which is highly sensitive to environment and occurs very quick and can not be repeated. Therefore, this period is called golden period. The previous reseacrh conveyed that $14 \%$ of toddlers are impaired development, aboth fine motoric and gross motoric, hearing disorder, under intelegence, speech delay. The result of preliminary of this study, there were 2 of 5 children had social independence disorder. It was caused by the external factors including parenting, economic, environment and nutrition. Objective of this study is to know the association of parenting and development in pre school children in Mentari Pre School North Sambi rampak village, Kotaanyar, Probolinggo district. This study used quantitative study with analytic correlational and crosssectional approach. The population is all mother and pre school children in Mentari Pre School 2015. The sample of this study is some mother and pre school children a number of 50 person. Sampling is purposive sampling with spearman rank test. The result shows that $p$ value $0,04<\alpha(0,05)$,so Ho is reject.The conclution is there correlation of parenting and development in pre school children in Mentari Pre School North Sambi rampak village, Kotaanyar, Probolinggo district.
\end{abstract}

Keywords: parenting, development, pre school children. 


\section{PENDAHULUAN}

Perkembangan adalah bertambahnya kemampuan dalam struktur dan fungsi tubuh yang lebih lengkap, memiliki pola yang teratur dan dapat diramalkan sebagai hasil dari proses pematangan. Dalam hal ini menyangkut proses diferensiasi sel-sel tubuh, jaringan tubuh, organ dan sistem organ yang berkembang sedemikian rupa sehingga masing-masing dapat memenuhi fungsinya (Soetjiningsih, 2014).

Periode penting dalam perkembangan anak adalah pada masa balita, termasuk masa anak pra sekolah (Soetjiningsih, 2014). Anakmempunyai rentang usia 3-5 tahun (Wong, 2008). Periode lima tahun pertama kehidupan merupakan masa yang sangat peka terhadap lingkungan dan berlangsung sangat pendek serta tidak dapat diulang lagi, maka masa tersebut disebut "masa keemasan" (golden period) (Suryawan, 2010).

Selain itu, pada lima tahun pertama seorang anak terbentuk dasar-dasar kepribadian manusia, kemampuan penginderaan, berpikir, kemampuan bahasa, berbicara, bertingkah laku sosial, perkembangan motorik kasar dan motorik halus serta kualitas perkembangan pada masa anak khususnya anak pra sekolah sangat menentukan banyak aspek kehidupan, baik itu aspek kesehatan, aspek prestasi belajar, aspek intelektualitas, aspek produkstivitas di kemudian hari (Suryawan, 2010).

Berdasarkan data Pusdatin Kemenkes RI (2014), jumlah anak pra sekolah di Indonesia sangat besar, yaitu sekitar 9.679.481 sedangkan di Propinsi Jawa Timur sendiri jumlah anak pra sekolah sebesar 1.218.756. Berdasarkan data tersebut, sebagai calon generasi penerus bangsa, kualitas perkembangan balita di Indonesia pada umumnya dan di Jawa Timur khususnya, perlu mendapat perhatian serius yaitu mendapat gizi yang baik, stimulasi yang memadai serta terjangkau oleh pelayanan kesehatan berkualitas termasuk deteksi dan intervensi dini penyimpangan perkembangan. Selain itu, berbagai faktor lingkungan yang dapat mengganggu perkembangan anak juga perlu dieliminasi (Jinan, 2015).
Menurut Depkes RI (2012) menyatakan bahwa $14 \%$ balita Indonesia mengalami gangguan perkembangan, baik perkembangan motorik halus dan kasar, gangguan pendengaran, kecerdasan kurang dan keterlambatan bicara. Pada tahun 2010 di Rumah Sakit Umum Dr. Soetomo di Surabaya, dijumpai 133 kasus pada anak dan remaja dengan gangguan perkembangan motorik kasar maupun halus (Suryawan, 2010).

Hasil studi pendahuluan di TK Mentari melalui wawancara dengan Kepala Sekolah diketahui bahwa dari 5 orang anak, terdapat 2 anak yang mengalami ganguan sosial kemandirian, anak cenderung pendiam, menyendiri dan bergantung kepada orang tuanya sedangkan 3 orang anak lainnya tidak ada gangguan perkembangan.

Faktor penyebab terganggunya perkembangan anak pra sekolah yaitu karena faktor intrinsik dan ekstrinsik serta faktor pendukung. Faktor instrinsik yang mempengaruhi kegagalan berkembang terutama berkaitan dengan terjadinya penyakit pada anak, yaitu kelainan kromosom sindorm down/ turner, kelainan pada sistem endokrin misalnya kekurangan hormon tiroid, kekurangan hormon pertumbuhan atau kekurangan hormon lainnya, kerusakan otak, kelainan sistem jantung, pernafasan, anemia atau penyakit darah lainnya, kelainan pada sistem pencernaan, ras, etnis, bangsa, jenis kelamin, umur, dan faktor ekstrinsik yang meliputi faktor psikologis dan sosial (misalnya tekanan emosional akibat penolakan atau tekanan dari orang tua, pola asuh orang tua), depresi, faktor ekonomi, faktor lingkungan sedangkan faktor pendukung yaitu terpenuhinya kebutuhan gizi pada anak, peran aktif orang tua, lingkungan yang merangsang semua aspek perkembangan anak, peran aktif anak, pendidikan orang tua (Soetjiningsih, 2014).

Akibat terganggunya perkembangan pada anak pra sekolah yaitu pada umur tertentu anak tidak dapat menguasai tugas perkembangan yang diharapkan kelompok sosialnya, anak tidak dapat melakukan gerak tertentu dan anak akan terhambat 
dalam mengakses sumber-sumber eksternal serta regulasi emosi dan kecerdasan serta terganggunya interaksi sosial dengan orang lain (Azizahnur, 2012). Selain itu, akibat tidak terpantaunya perkembangan anak balita oleh orang tua balita, mengakibatkan orang tua tidak mengetahui apakah perkembangan anaknya dalam keadaan normal atau tidak.

Upaya yang dapat dilakukan untuk mengoptimalkan perkembangan anak pra sekolah salah satunya dengan memenuhi kebutuhan anak pra sekolah dalam kebutuhan asuh. Dalam hal pola asuh, orang tua mempunyai cara tersendiri dalam mengasuh dan membimbing anaknya. Cara dan pola tersebut akan berbeda antara orang tua satu dengan orang tua yang lainnya. Kebutuhan pola asuh yang dapat diberikan orang tua pada anak yaitu dengan cara memberikan perhatian, peraturan, disiplin, hadiah, hukuman serta tanggapan keinginan anaknya.

Tujuan penelitian untuk menganalisis hubungan pola asuh orang tua dengan perkembangan anak pra sekolah di TK Mentari Desa Sambi Rampak Lor Kecamatan Kota Anyar Kabupaten Probolinggo.

\section{METODE PENELITIAN}

Desain yang digunakan dalam penelitian ini menggunakan pendekatan kuantitatif dimana peneliti akan bekerja dengan angka-angka sebagai perwujudan atas sesuatu yang diamati atau diteliti. Rancangan penelitian ini analitik korelasional, yaitu penelitian yang bertujuan untuk mencari hubungan antara variabel independen dan variabel dependen, dengan pendekatan crossectional dimana data dikumpulkan pada waktu yang sama (Hidayat, 2011). Jenis uji statistik Spearman Rank.

Populasi penelitian ini adalah Seluruh ibu dan anak pra sekolah di TK Mentari Tahun 2015. Sampel penelitian ini yaitu sebagian ibu dan anak pra sekolah sejumlah 50 responden. Teknik sampling penelitian ini yaitu purposive sampling.
Instrumen yang digunakan dalam penelitian ini yaitu angket dan lembar observasi DDTK Denver II.

\section{HASIL DAN PEMBAHASAN}

\section{HASIL}

\section{Distribusi Frekuensi Orang Tua Responden Berdasarkan Umur}

Tabel1. Ditribusi Frekuensi Orang Tua Responden Berdasarkan Umur di TK Mentari Desa Sambirampak Lor Kecamatan Kota Anyar Kabupaten Probolinggo

\begin{tabular}{ccc}
\hline Umur (Tahun) & Frekuensi & $\%$ \\
\hline$<20$ & 0 & 0 \\
$20-40$ & 45 & 90 \\
$40-60$ & 5 & 10 \\
\hline Jumlah & 50 & 100 \\
\hline
\end{tabular}

Berdasarkan tabel 1 diketahui bahwa hampir seluruh orang tua responden yaitu 45 orang $(90 \%)$ memiliki umur antara 20 40 tahun.

\section{Distribusi Frekuensi Orang Tua Responden Berdasarkan Tingkat Pendidikan}

Tabel 2. Distribusi Frekuensi Orang Tua Responden Berdasarkan Tingkat Pendidikan di TK Mentari Desa Sambirampak Lor Kecamatan Kota Anyar Kabupaten Probolinggo

\begin{tabular}{ccc}
\hline $\begin{array}{c}\text { Tingkat } \\
\text { Pendidikan }\end{array}$ & Frekuensi & $\%$ \\
\hline SD & 16 & 32 \\
SMP & 21 & 42 \\
SMA & 11 & 22 \\
PT & 2 & 4 \\
\hline Jumlah & 50 & 100 \\
\hline
\end{tabular}

Berdasarkan tabel 2 diketahui bahwa hampir setengah orang tua responden memiliki tingkat pendidikan SMP sebanyak 21 orang (42\%) dan SD sebanyak 16 orang (32\%). 


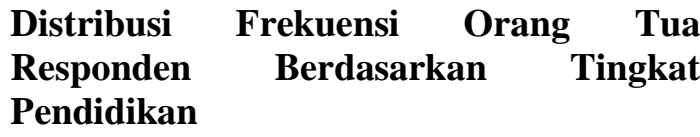

Tabel 3. Distribusi Frekuensi Orang Tua Responden Berdasarkan Tingkat Pendidikan di TK Mentari Desa Sambirampak Lor Kecamatan Kota Anyar Kabupaten Probolinggo

\begin{tabular}{ccc}
\hline $\begin{array}{c}\text { Status } \\
\text { Pekerjaan }\end{array}$ & Frekuensi & \% \\
\hline IRT & 42 & 84 \\
Swasta & 1 & 2 \\
Wiraswasta & 7 & 14 \\
TTNI/ POLRI & 0 & 0 \\
PNS & 0 & 0 \\
\hline Jumlah & 50 & 100 \\
\hline
\end{tabular}

Berdasarkan tabel 3 diketahui bahwa hampir seluruhnya status pekerjaan orang tua responden yaitu 42 orang $(84 \%)$ sebagai ibu rumah tangga (IRT).

Pola Asuh Orang Tua Anak Pra Sekolah di TK Mentari Desa Sambirampak Lor Kecamatan Kota Anyar Kabupaten Probolinggo

Tabel 4. Distribusi Frekuensi Pola Asuh Orang Tua Anak Pra Sekolah di TK Mentari Desa Sambirampak Lor Kecamatan Kota Anyar Kabupaten Probolinggo

\begin{tabular}{ccc}
\hline Pola Asuh & Frekuensi & $\%$ \\
\hline Otoriter & 0 & 0 \\
Demokratis & 44 & 88 \\
Permisif & 6 & 12 \\
\hline Jumlah & 50 & 100 \\
\hline
\end{tabular}

Berdasarkan tabel 4 diketahui bahwa hampir seluruhnya pola asuh orang tua responden yaitu 44 orang ( $88 \%$ ) menerapkan pola asuh demokratis dan hanya sebagian kecil orang tua responden yaitu 6 orang $(12 \%)$ menerapkan pola asuh permisif.

Perkembangan Anak Pra Sekolah di TK Mentari Desa Sambirampak Lor Kecamatan Kota Anyar Kabupaten Probolinggo.

Tabel 5. Distribusi Frekuensi Perkembangan Anak Pra Sekolah di TK Mentari Desa Sambirampak Lor Kecamatan Kota Anyar Kabupaten Probolinggo

\begin{tabular}{ccc}
\hline Perkembangan & Frekuensi & $\%$ \\
\hline Abnormal & 6 & 12 \\
Meragukan & 10 & 20 \\
Normal & 34 & 68 \\
Tidak dapat diuji & 0 & 0 \\
\hline Jumlah & 50 & 100 \\
\hline
\end{tabular}

Berdasarkan tabel 5 diketahui bahwa sebagian besar perkembangan anak pra sekolah yaitu 34 (68\%) memiliki perkembangan normal dan hanya sebagian kecil anak pra sekolah yaitu $6(12 \%)$ yang memiliki perkembangan abnormal.

Hubungan Pola Asuh Orang Tua dan Perkembangan Anak Pra Sekolah di TK Mentari Desa Sambirampak Lor Kecamatan Kota Anyar Kabupaten Probolinggo

Tabel 6. Silang HubunganPola Asuh Orang Tua dan Perkembangan Anak Pra Sekolah di TK Mentari Desa Sambirampak Lor Kecamatan Kota Anyar Kabupaten Probolinggo

\begin{tabular}{|c|c|c|c|c|c|c|c|c|c|c|}
\hline \multirow{3}{*}{$\begin{array}{l}\text { Pola Asuh } \\
\text { Orang Tua }\end{array}$} & \multicolumn{8}{|c|}{ Perkembangan Anak Pra Sekolah } & \multirow{2}{*}{\multicolumn{2}{|c|}{ Total }} \\
\hline & \multicolumn{2}{|c|}{ Abnormal } & \multicolumn{2}{|c|}{ Meragukan } & \multicolumn{2}{|c|}{ Normal } & \multicolumn{2}{|c|}{$\begin{array}{l}\text { Tidak dapat } \\
\text { diuji }\end{array}$} & & \\
\hline & $\mathrm{F}$ & $\%$ & F & $\%$ & $\mathrm{~F}$ & $\%$ & $\mathrm{~F}$ & $\%$ & $\mathrm{~F}$ & $\%$ \\
\hline Otoriter & 0 & 0 & 0 & 0 & 0 & 0 & 0 & 0 & 0 & 0 \\
\hline Demokratis & 4 & 66,7 & 7 & 70 & 33 & 97 & 0 & 0 & 44 & 88 \\
\hline Permisif & 2 & 33,3 & 3 & 30 & 1 & 3 & 0 & 0 & 6 & 12 \\
\hline \multirow[t]{2}{*}{ Jumlah } & 6 & 100 & 10 & 100 & 34 & 100 & 0 & 0 & 50 & 100 \\
\hline & & & \multicolumn{2}{|c|}{$\mathrm{p}$ value $=0,0$} & \multicolumn{2}{|c|}{$\alpha=0,05$} & & & & \\
\hline
\end{tabular}


Berdasarkan tabel 6 diketahui bahwa hampir seluruh orang tua yang menerapkan pola asuh demokratis, memiliki perkembangan anak yang normal yaitu sebanyak 33 orang (97\%), sedangkan orang tua yang menerapkan pola asuh permisif, cenderung memiliki perkembangan anak yang abnormal yaitu sebanyak 2 orang $(33,3 \%)$.

\section{PEMBAHASAN}

\section{Pola Asuh Orang Tua Anak Pra Sekolah di TK Mentari Desa Sambirampak Lor Kecamatan Kota Anyar Kabupaten Probolinggo}

Berdasarkan tabel 4 diketahui bahwa hampir seluruhnya pola asuh orang tua responden yaitu 44 orang (88\%) menerapkan pola asuh demokratis dan hanya sebagian kecil orang tua responden yaitu 6 orang $(12 \%)$ menerapkan pola asuh permisif.

Pola asuh orang tua adalah pola perilaku yang diterapkan pada anak bersifat relatif konsisten dari waktu ke waktu. Pola perilaku ini dirasakan oleh anak, dari segi negatif maupun positif. Pola asuh yang ditanamkan tiap keluarga berbeda, hal ini tergantung pandangan dari tiap orang tua (Baumrind, 1967 dalam Naibaho, 2012). Jenisnya dibagi menjadi pola asuh otoriter, demokratis dan permisif (Silalahi, 2014).

Orang tua yang menerapkan pola asuh demokratis akan menghasilkan karakteristik anak-anak yang mandiri, dapat mengontrol diri, mempunyai hubungan baik dengan teman, mampu menghadapi stres, mempunyai minat terhadap hal-hal baru dan kooperatif terhadap orang lain, sedangkan yang menerapkan pola asuh otoriter akan menghasilkan karakteristik anak penakut, pendiam, tertutup, tidak berinisiatif, gemar menentang, suka melanggar norma, berkepribadian lemah, cemas dan menarik diri. Demikian pula orang tua yang menerapkan pola asuh permisif akan menghasilkan karakteristik anak-anak impulsif, agresif, tidak patuh, manja, kurang madiri, mau menang sendiri, kurang percaya diri dan kurang matang sosial (Sudarsih, 2016).

Sedangkan faktor yang mempengaruhi pola asuh orang tua yaitu, umur orang tua, keterlibatan orang tua, pendidikan, pengalaman sebelumnya dalam mengasuh anak, stres orang tua, hubungan suami isteri.

Hal ini sesuai dengan hasil penelitian pada tabel 1 diketahui bahwa hampir seluruh orang tua responden yaitu 45 orang (90\%) memiliki umur antara 20-40 tahun. Semakin matang usia orang tua, memungkinkan orang tua untuk siap secara fisik maupun psikososial dalam membentuk rumah tangga dan menjadi orang tua.

Hasil penelitian lainnya sesuai tabel 2 diketahui bahwa hampir setengah orang tua responden memiliki tingkat pendidikan SMP sebanyak 21 orang (42\%) dan SD sebanyak 16 orang $(32 \%)$. Berdasarkan hasil penelitian tersebut bahwa hampir setengah responden memiliki tingkat pendidikan menengah pertama. Hal ini sesuai dengan pendapat Notoatmodjo (2010), bahwa semakin tinggi pendidikan seseorang maka semakin tinggi pula tingkat pengetahuan seseorang, pengalaman akan semakin bertambah, yang akan mempengaruhi orang tersebut untuk bersikap dan berperilaku. Pendidikan dan pengalaman orang tua dalam perawatan anak akan mempengaruhi kesiapan mereka menjalankan peran pengasuhan.

Hasil penelitian berikutnya pada tabel 3 diketahui bahwa hampir seluruhnya status pekerjaan orang tua responden yaitu 42 orang (84\%) sebagai ibu rumah tangga (IRT). Orang tua yang mempunyai pekerjaan sebagai ibu rumah tangga memberikan peluang yang lebih banyak dalam keterlibatan untuk mengasuh anaknya secara langsung, yang dalam hal ini juga mempengaruhi pola asuh orang tua akan asih dan asah.

\section{Perkembangan Anak Pra Sekolah di TK Mentari Desa Sambirampak Lor Kecamatan Kota Anyar Kabupaten Probolinggo}

Berdasarkan tabel 5 diketahui bahwa sebagian besar perkembangan anak pra sekolah yaitu 34 (68\%) memiliki perkembangan normal dan hanya sebagian kecil anak pra sekolah yaitu $6(12 \%)$ yang memiliki perkembangan abnormal.

Perkembangan adalah bertambahnya kemampuan dalam struktur dan fungsi tubuh yang lebih lengkap, memiliki pola yang teratur dan dapat diramalkan sebagai hasil 
dari proses pematangan. Dalam hal ini menyangkut proses diferensiasi sel-sel tubuh, jaringan tubuh, organ dan sistem organ yang berkembang sedemikian rupa sehingga masing-masing dapat memenuhi fungsinya (Soetjiningsih, 2014).

Sedangkan faktor yang mempengaruhi perkembangan anak yaitu Faktor instrinsik yang mempengaruhi kegagalan berkembang terutama berkaitan dengan terjadinya penyakit pada anak, yaitu kelainan kromosom sindorm down/ turner, kelainan pada sistem endokrin misalnya kekurangan hormon tiroid, kekurangan hormon pertumbuhan atau kekurangan hormon lainnya, kerusakan otak, kelainan sistem jantung, pernafasan, anemia atau penyakit darah lainnya, kelainan pada sistem pencernaan, ras, etnis, bangsa, jenis kelamin, umur, dan faktor ekstrinsik yang meliputi faktor psikologis dan sosial (misalnya tekanan emosional akibat penolakan atau tekanan dari orang tua, pola asuh orang tua), depresi, faktor ekonomi, faktor lingkungan sedangkan faktor pendukung yaitu terpenuhinya kebutuhan gizi pada anak, peran aktif orang tua, lingkungan yang merangsang semua aspek perkembangan anak, peran aktif anak, pendidikan orang tua (Soetjiningsih, 2014).

Hal ini sesuai dengan hasil penelitian tabel 3 diketahui bahwa hampir seluruhnya status pekerjaan orang tua responden yaitu 42 orang $(84 \%)$ sebagai ibu rumah tangga (IRT). Orang tua yang mempunyai pekerjaan sebagai ibu rumah tangga memberikan peluang yang lebih banyak dalam keterlibatan untuk mengasuh anaknya secara langsung, yang dalam hal ini juga mempengaruhi pola asuh, asih dan asah.

\section{Hubungan Pola Asuh Orang Tua dan Perkembangan Anak Pra Sekolah di TK Mentari Desa Sambirampak Lor Kecamatan Kota Anyar Kabupaten Probolinggo}

Berdasarkan tabel 6 diketahui bahwa hampir seluruh orang tua yang menerapkan pola asuh demokratis, memiliki perkembangan anak yang normal yaitu sebanyak 33 orang (97\%), sedangkan orang tua yang menerapkan pola asuh permisif, cenderung memiliki perkembangan anak yang abnormal yaitu sebanyak 2 orang $(33,3 \%)$.

Hasil analisis data penelitian dengan rumus Spearman Rank, diperoleh hasil $\mathrm{p}$ value $=0,04$ pada $\alpha=0,05$ sehingga menolak $\mathrm{H} 0$ yang berarti bahwa Ada hubungan Pola Asuh Orang Tua dan Perkembangan Anak Pra Sekolah di TK Mentari Desa Sambirampak Lor Kecamatan Kota Anyar Kabupaten Probolinggo.

Hasil penelitian tersebut diatas sesuai dengan pendapat Notoatmodjo (2010) bahwa faktor yang mempengaruhi pola asuh yaitu umur orang tua, keterlibatan orang tua, pendidikan, pengalaman sebelumnya dalam mengasuh anak, stres orang tua, hubungan suami isteri. Hal ini juga sejalan menurut Soetjiningsih (2005) bahwa terdapat faktor eksternal yang mempengaruhi perkembangan anak, yaitu faktor psikologis dan sosial (misalnya tekanan emosional akibat penolakan atau tekanan dari orang tua, pola asuh orang tua), depresi, faktor ekonomi, faktor lingkungan sedangkan faktor pendukung yaitu terpenuhinya kebutuhan gizi pada anak, peran aktif orang tua, lingkungan yang merangsang semua aspek perkembangan anak, peran aktif anak, pendidikan orang tua.

Hal ini sesuai menurut pendapat Sudarsih (2016) bahwa orang tua yang menerapkan pola asuh demokratis akan menghasilkan karakteristik anak-anak yang mandiri, dapat mengontrol diri, mempunyai hubungan baik dengan teman, mampu menghadapi stres, mempunyai minat terhadap hal-hal baru dan kooperatif terhadap orang lain, sedangkan yang menerapkan pola asuh otoriter akan menghasilkan karakteristik anak penakut, pendiam, tertutup, tidak berinisiatif, gemar menentang, suka melanggar norma, berkepribadian lemah, cemas dan menarik diri. Demikian pula orang tua yang menerapkan pola asuh permisif akan menghasilkan karakteristik anak-anak impulsif, agresif, tidak patuh, manja, kurang madiri, mau menang sendiri, kurang percaya diri dan kurang matang sosial yang hal ini dapat mempengaruhi perkembangan anak. 


\section{KESIMPULAN DAN SARAN}

\section{Kesimpulan}

Hampir seluruhnya pola asuh orang tua responden yaitu 44 orang $(88 \%)$ menerapkan pola asuh demokratis dan hanya sebagian kecil orang tua responden yaitu 6 orang $(12 \%)$ menerapkan pola asuh permisif.

Sebagian besar perkembangan anak pra sekolah yaitu memiliki perkembangan normal dan hanya sebagian kecil anak pra sekolah yang memiliki perkembangan abnormal.

\section{REFERENSI}

Azizahnur. (2012). Perkembangan Fisik dan Motorik pada Anak. (internet). Bersumber dari: http://azizahnurblogspot.com/2012/10 /perkembangan-fisik-dan-motorikpada-anak.html. Diakses tanggal 20 April 2015.

Depkes RI. (2011) . Profil Kesehatan Indonesia Tahun 2011. Jakarta. Depkes RI.

Jinan, R. (2015). Perkembangan Balita. (Internet). Bersumber dari: repository.usu.ac.id/bitstream/.../5/Ch apter\%20I.pdf. Diakses tanggal 21 April 2015.

Hidayat, A.A.A. (2011). Metode Penelitian Keperawatan dan Teknik Analisis Data. Jakarta. Salemba Medika.

Naibalo. (2012). Hubungan Pola Asuh Orang Tua dengan Perilaku Kesehatan Remaja. (Internet). Bersumber dari: repository.usu.ac.id/bitsream/handle/12 3456789/31319/Chapter

II.pdf;jsessionid $=6 D 422 A E 54 B 348 F B E$ $89615 C 26831 A 3 F C 9$ ? sequence $=4$. Diakses tanggal 1 Maret 2015.
Ada hubungan pola asuh orang tua dan perkembangan anak pra sekolah di TK Mentari Desa Sambirampak Lor Kecamatan Kota Anyar Kabupaten Probolinggo.

\section{Saran}

Sebaiknya orang tua menerapkan pola asuh demokratis dalam mendidik, mengasuh anaknya dan pentingnya keterlibatan orang tua secara langsung dalam mengasuh anaknya sendiri dengan tetap memberikan stimulasi atau asah setiap saat dengan pengawasan dan bimbingan orang tua dan dengan tetap menghargai hak anak.

Notoatmodjo, S. (2010). Metodologi Penelitian Kesehatan, Jakarta: Rineka Cipta.

Silalahi, Y. N. (2014). Tipe Pola Asuh. (Internet). Bersumber dari: repository.usu.ac.id/bitstream/123456 789/40378/4/Chapter\%20II.pdf.

Diakses tanggal 1 Maret 2015.

Soetjiningsih, dkk. (2014). Buku Ajar Tumbuh Kembang Anak dan Remaja Edisi 2, Jakarta. EGC.

Sudarsih, S. (2016). Pola Asuh Orang Tua pada Remaja yang Memiliki Perilaku Merokok di SMPN 1 Mojoanyar, Jabon, Mojokerto. Jurnal Medica Majapahit, 8 (1). Hal: 14-21.

Suryawan, A, dkk. (2010). Deteksi Dini Tanda dan Gejala Penyimpangan Pertumbuhan dan Perkembangan Anak, Surabaya. IDAI Jatim.

Wong, dkk. (2008). Buku Ajar Keperawatan Pediatrik Volume 1. Jakarta. EGC. 